\title{
DYNAMICS OF THE CONTENT OF PHENOLIC COMPOUNDS IN THE SHOOTS OF THE REPRESENTATIVES OF THE FAMILY CORNACEAE BERCHT. ET J. PRESL IN THE PERIOD OF WINTER DORMANCY
}

\author{
Levon Volodymyr*, Klymenko Svitlana, Tesliuk Maxim
}

M.M. Gryshko National Botanical Garden of NAS of Ukraine, Kyiv, Ukraine

\author{
Received 10.3. 2017 \\ Revised 22. 5. 2017 \\ Published 29.11. 2017
}

The study of phenolic compounds in shoots of the family Cornaceae Bercht. et J. Presl due to the sharp fluctuations of temperatures during winter dormancy. Analysis of the obtained experimental data showed that the species and varieties of the family Cornaceae differ significantly in content of phenolic compounds in the period of sharp fluctuations of temperatures. Detailed analysis of the graphic depends of the content of phenolic compounds in the shoots of plants of the family Cornaceae of the average daily temperature in the period of winter dormancy, it has been noticed quite a lot of differences in the dynamics of accumulation of phenols in different species of the genus Cornus L. and Cynoxylon Raf. Were established in the shoots of Cornus mas L. dynamics of the content of phenolic compounds in the period under study has wider amplitude than that of Cornus officinalis Sieb. et Zucc. and Cornus sessilis Torr. This is consistent with the fact that Cornus mas is an indigenous species that is well adapted to the conditions of Northern Forest-Steppe of Ukraine and is the most winter-hardy of all studied species. It is established that Cynoxylon japonica Nakai has a larger amplitude in the content of phenols in the temperature change unlike Cynoxylon florida L., where the change in the accumulation of phenols occurs more smoothly. Cynoxylon japonica responds to more short-term changes in temperature contrast Cynoxylon florida, where the changes of accumulation of phenolic compounds occur only during prolonged cold snaps, or warming. All this indicates a higher frost resistance Cynoxylon japonica in relation to Cynoxylon florida.

Keywords: phenolic compounds; Cornaceae; Cornus mas; Cornus officinalis; Cornus sessilis; Cynoxylon florida; Cynoxylon japonica; forest-steppe of Ukraine

\section{Introduction}

The species of polymorphic family Cornaceae Bercht. et J. Presl are poorly spreaded and studied. According to different authors there are from 50 to 110 species. Most of them are valued as ornamental and agroforestry, some like fruit and medicinal.

From a large number of species of cornelian cherry, a few species have edible fruits - Cornus mas $L$. (common Eurasian species), Cornus officinalis Sieb. et Zucc., native for Japan, Cornus sessilis Torr. is from California, and several species of the genus Cynoxylon Raf. - Cynoxylon japonica Nakai, Cynoxylon florida L., native to North America.

Despite the value species of the cornelian cherry and the possibility of their versatile use, in 50s years of the twentieth century in M.M. Gryshko National Botanical Garden the creation of the collection of

*Corresponding author: Volodymyr Levon, M.M. Gryshko National Botanical Garden of NAS of Ukraine, Kyiv, Ukraine, $₫$ vflevon@gmail.com 
the family Cornaceae was created. Now the collection includes more than 30 species in the family Cornaceae.

Species of the genus Cynoxylon, introduced in the last 20 years: Cynoxylon japonica in 1994 (Oregon, USA), Cynoxylon florida in 2008.

All introduced in Ukraine species of genus Cynoxylon have edible fruits, which are red of various shades, sweet and sour taste, strawberry flavor. For valuable economic properties and decorativeness, they are not worse than representatives of the local flora, but also surpass them.

Therefore, they are promising as fruit plants, in addition, they are valuable medicinal raw material, in particular, the bark of shoots and roots of Cynoxylon florida used as a substitute for quinine, the preparations have a tonic, astringent and stimulating properties. Wood of Cynoxylon has dark colour, resistant to biological destruction and has an extremely high strength (Кустовська, 1998).

Today members of the genus are widely cultivated in the United States, Western Europe (Spain, Portugal), Japan as ornamental plants, less fruit: Cynoxylon japonica (China, Japan).

The area of Cynoxylon genus covers the temperate and subtropical regions of the Northern hemisphere: North America, East and South-East Asia and Africa. Cynoxylon cultivated in the United States, Canada, South and Western Europe, Southeast and East Asia, in the Caucasus (Janes, 1993; Кустовська, 1998).

Cynoxylon japonica was introduced in National Botanical garden in 1994 from Oregon (USA). Some annual plant height of $80-100 \mathrm{~cm}$ was planted at sites of the Department of fruit plants acclimatization, where it held regular phenological observations were evaluated wintering and drought resistance, productivity, and decorativeness.

Biochemical studies of the content of biologically active substances in new species of the family Cornaceae in the conditions of the Forest-Steppe of Ukraine held for the first time as the actual adaptive capacity of plants of these species in the absence of such data in the literature. The reason is that the study species have not been used until now as fruit and ornamental is in the collections of some Botanical gardens and arboretums.

Frost resistance is determined by many factors, in particular the important role of secondary metabolites involved in the biochemical adaptation of plants. This group includes phenols. These compounds are formed in all organs of plants from sugars and participate in the process of cellular respiration, transferring hydrogen from oxidative molecules. Phenolic compounds exhibit a strong effect on the growth of plants, inhibiting germination of seeds, growth of stems and roots. They have strong anti-bacterial properties and provide plant immunity to fungal and especially to bacterial infection (Блажей, 1977).

In adverse conditions, plants synthesize increased amount of phenolic compounds, because in most cases they have a protective effect (Capanyy, 1968). Often the healthy plant has no protective phenols, but they are formed in it as reaction to infection with the causative agent of a disease. Phenolic compounds have an important role in wound healing, cell division, and in protecting tissues from penetrating radiation, free radicals, mutagens and strong oxidizers.

Phenolic compounds can act as low molecular weight antioxidants, protect cells from the effects of oxidative stress developing in conditions of hypothermia (Larson, 1988; Terao, 1994; Rice-Evans, 1997; Wingsle, 1999). Having high reaction activity due to the presence in the structure of aromatic rings and free hydroxyl groups, they can easily engage in free-radical reactions and connect the 
active variety of oxygen and peroxy radicals produced in the cells under stress conditions (Wang, 1998; Kondo, 2000; Zhao, 2002).

A characteristic feature of the phenolic compounds that distinguish them from many other secondary metabolites is their ability to interact with proteins by forming hydrogen bonds (Запрометов, 1974; Барабой, 1976). In this regard, some of them may participate in the regulation of enzyme activity, affecting, therefore, on the metabolic processes in the period of low-temperature adaptation.

The aim of our study was to determine the content of phenolic compounds in shoots of different species, varieties and cultivars of the family of Cornaceae in the winter and the dependence of these indicators of frost resistance of plants.

\section{Materials and methodology}

The experiment was made in January-February 2016 this period there was a fluctuation of temperatures from $-9{ }^{\circ} \mathrm{C}$ to $+7{ }^{\circ} \mathrm{C}$. Samples were collected weekly. Objects of research were the representatives of the genus Cornus (C. mas, C. officinalis, C. sessilis) and Cynoxylon (C. florida and C. japonica).

For quantitative definition of phenols the methodology based on oxidation of a reactant of FolinChokolta containing a tungstate of sodium and phosphomolybdate of sodium with formation of a blue complex, having absorption maximum at the wavelength of 730 nanometers, which intensity of coloring is estimated by a photoelectrocolorimetric method (Ксендзова, 1971) was used.

For objects visual observations studied conducted general condition of the plants in the spring to determine their hardiness (Соколов, 1957).

\section{Results and discussion}

Analysis of the obtained experimental data showed that the species and varieties of the family Cornaceae differ significantly in content of phenolic compounds in the period of sharp fluctuations of temperatures (Figure 1,2).

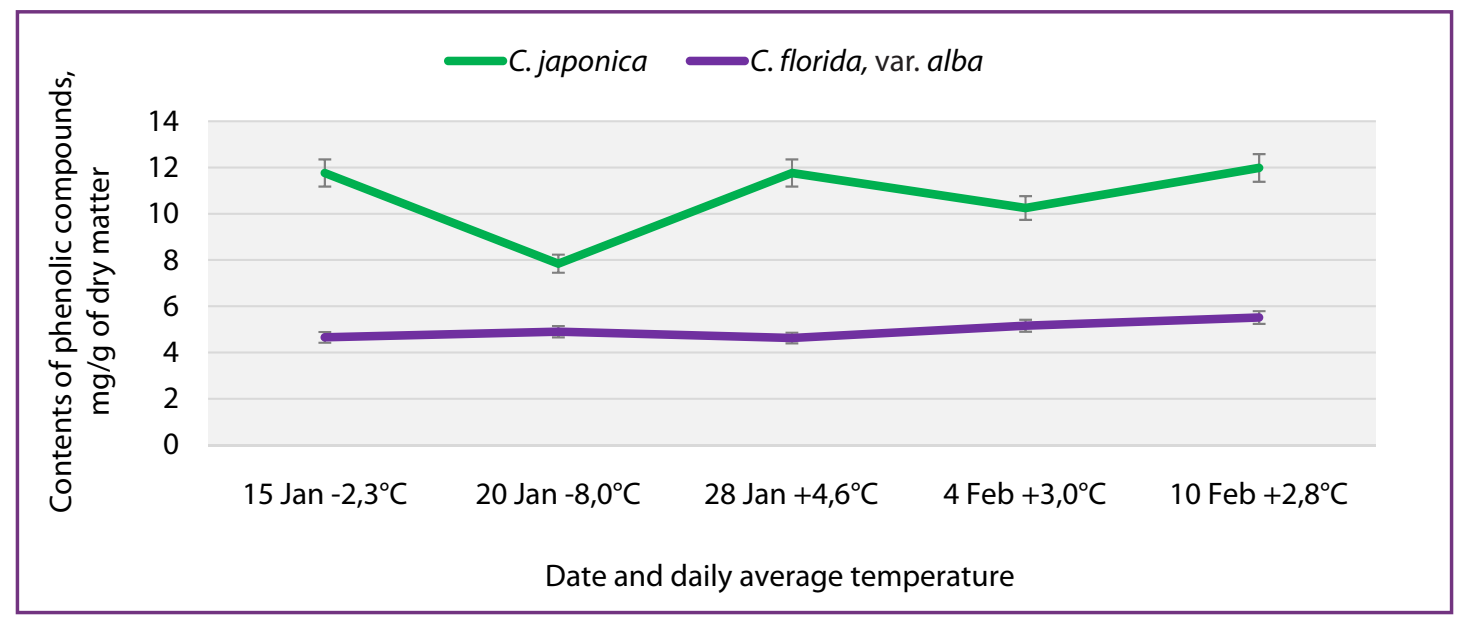

Figure 1 The total content of phenolic compounds in shoots of Cynoxylon japonica Nakai and Cynoxylon florida L. (var. alba) in the period of winter dormancy 


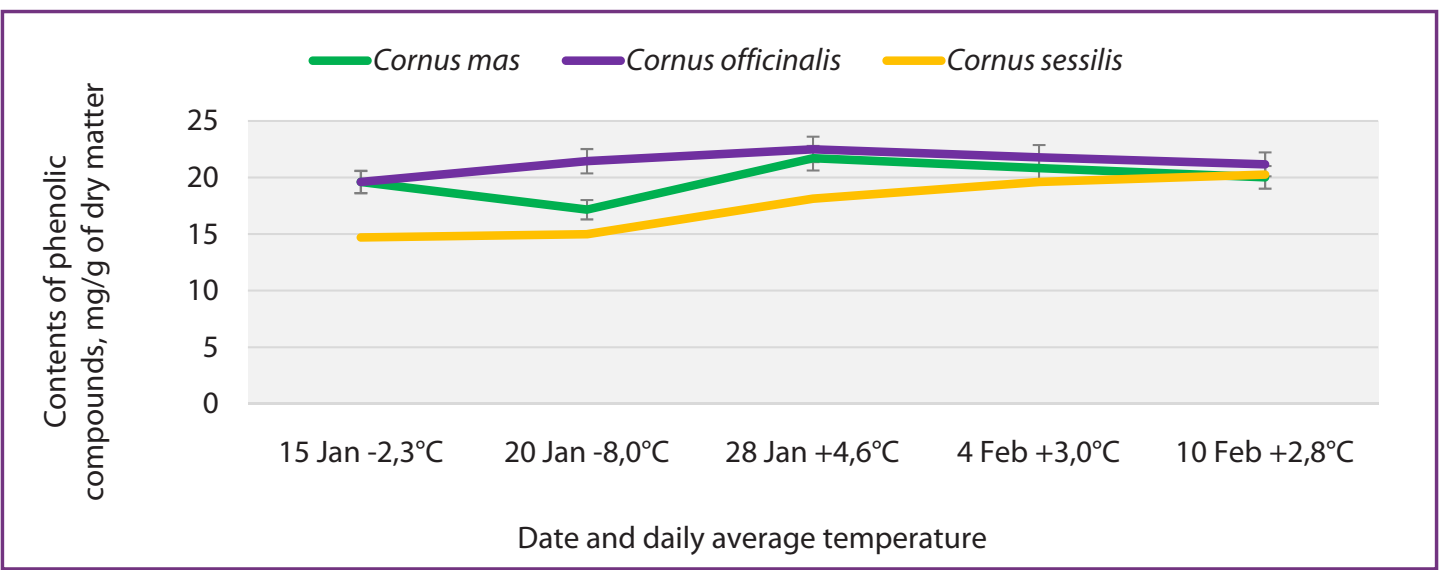

Figure 2 The total content of phenolic compounds in shoots of Cornus mas L., Cornus officinalis Sieb. et Zucc. and Cornus sessilis Torr. in the period of winter dormancy

The detailed analysis of the graphic dependences of the content of phenolic compounds in the shoots of the members of the family Cornaceae of the average daily temperature in the period of winter dormancy, it has been noticed quite a lot of differences in the dynamics of accumulation of phenols in different species of the genus Cornus and Cynoxylon. Dynamics of the content of phenolic compounds in the shoots of Cornus mas were established in the period under study, they have a wider amplitude than that of Cornus officinalis and Cornus sessilis. This is consistent with the fact that Cornus mas is an indigenous species that is well adapted to the conditions of Northern Forest-Steppe of Ukraine and is the most winter-hardy of all studied species.

Despite the fact that Cornus officinalis is also quite winter-hardy species and occurs from regions of Japan with a rather continental climate, the change in the accumulation of phenolic compounds in shoots occurs more smoothly. Perhaps this is due to the long period of primary inductive stress reaction that is a consequence of various genetic and geographical origin.

Cornus sessilis, a native of Western North America (CA), does not respond to temperature changes by changing the rate of synthesis of phenolic compounds and, consequently, has lower winter hardiness.

Members of the genus Cynoxylon have a similar pattern. The Cynoxylon japonica has a larger amplitude in the content of phenols in the temperature change unlike Cynoxylon florida, where the change in the accumulation of phenols occurs more smoothly. Cynoxylon japonica responds to more short-term changes in temperature contrast Cynoxylon florida, where the changes of accumulation of phenolic compounds occur only during prolonged cold snaps, or warming. All this indicates a higher frost resistance Cynoxylon japonica in relation to Cynoxylon florida.

\section{Conclusions}

Due to the fact that the dynamics of the content of phenolic compounds in plants of the family Cornaceae virtually unexplored, the study of this issue was a priority. The increase in the content of phenolic compounds in plants of the family Cornaceae in the process of low-temperature adaptation testifies to their important role in protecting cells from the action of stress factors. Since the dynamics of the content of phenolic compounds in plants of the family Cornaceae reflects its 
interaction with the external environment, these compounds can be used as a biochemical marker to assess the level of adaptability.

\section{References}

Janes, N.A., Brand, A.l., Arnow, J. 1993. Kousa cornelian cherry. American nurseryman, vol. 178, no. 10, p. 40-47.

Kondo, N., Kawashima, M. 2000. Enhancement of the Tolerance to Oxidative Stress in Cucumber (Cucumis sativus L.) Seedlings by UV-B Irradiation: Possible Involvement of Phenolic Compounds and Antioxidative Enzymes. J. Plant Res., vol. 113, p. 311-317.

Larson, R.A. 1988. The antioxidants of higher plants. Phytochemistry, vol. 27, p. 969-978.

Rice-Evans, C.A., Miller, N.J., Paganga, G. 1997. Antioxidant properties of phenolic compounds. Trends in Plant Science, vol. 2, p. 152-159. ISSN 1360-1385.

Terao, J., Piskura, M., Yao, Q. 1994. Protective effect of epicatechin, epicatechin gallate and quercetin on lipid peroxidation in phospholipid bilayers. Archives of Biochemistry and Biophysics, vol. 308, p. 278-284.

Wang, M., Rangarajan, M., Shao, Y., Voie, E., Huang, T. 1998. Antioxidative phenolic compounds from sage (Salvia officinalis). J. Agric. Food Chem., vol. 46, p. 4869-4873. DOI: 10.1021/jf980614b

Wingsle, G., Karpinski, S., Hallgren, J. 1999. Low temperature, high light stress and antioxidant defence mechanisms in higher plants. Phyton (Austria), Special issue: Eurosilva 4, p. 253-268. ISSN 0079-2047.

Zhao, H., Zou, Q. 2002. Protective effects of exogenous antioxidants and phenolic compounds on photosynthesis of wheat leaves under high irradiance and oxidative stress. Photosynthetica, vol. 40, no. 4, p. 523-527.

Барабой, В.А. 1976. Биологическое действие растительных фенольных соединений. Киев: Наукова думка, 260 с.

Блажей, А.С., Шутый, Л.П. 1977. Фенольные соединения растительного происхождения. М.: Мир, 239 с.

Запрометов, М.Н., Николаева, Т.Н. 2003. Способность изолированных хлоропластов из листьев фасоли осуществлять биосинтез фенольных соединений. Физиология растений, т. 50, № 5, с. 699702. ISSN 0015-3303.

Ксендзова, Э.Н. 1971. Прием количественного определения фенольных соединений в растительных тканях. Бюл. Всесоюзн. н.-и. ин-та защиты растений, № 20, с. 55-58.

Кустовська, А.В. 1998. Критичний аналіз системи Cornaceae Dumort. Український ботанічний журнал, т. 55, № 6, с. 624-629.

Сарапуу, Л.П., Кефели, В.И. 1968. Фенольные соединения и рост растений. Фенольные соединения и их биологические функции. Мат. 1-го Всесоюз. симп. по фенольным соединениям. М.: Наука, с. $129-138$.

Соколов, С.Я. 1957. Современное состояние теории акклиматизации и интродукции растений. Тр. Ботан. ин-та. АН СССР. Интродукция растений и зелёное строительство, вып. 6, с. 34-42. 